\title{
Carcass characteristics and meat quality attributes in lambs reared indoors, on cultivated pasture, or on semi-natural pasture
}

\author{
Elin Stenberg ${ }^{1}$, Anders H. Karlsson ${ }^{1}$, Camilla Öhgren ${ }^{2}$ and Katarina Arvidsson-Segerkvist ${ }^{1}$ \\ ${ }^{1}$ Department of Animal Environment and Health, Swedish University of Agricultural Sciences, \\ P.O. Box 234, SE-53223 Skara, Sweden \\ ${ }^{2}$ RISE Research Institutes of Sweden, P.O. Box 5401, SE-40229 Gothenburg, Sweden. \\ e-mail: elin.stenberg@slu.se
}

\begin{abstract}
This study evaluated the effects of different lamb production systems on live weight gain (LWG), carcass quality and meat quality. Four production systems for weaned intact male lambs were examined: indoor feeding with grass silage and concentrate (group 1), grazing on cultivated pasture with (group 2) or without (group 3) concentrate, and grazing on semi-natural pasture (group 4). Live weight, carcass weight, dressing percentage, carcass conformation, fatness and $\mathrm{pH}$ decline were recorded at slaughter, and $\mathrm{M}$. longissimus thoracis et lumborum was analysed for colour, thawing and cooking loss, pH after 24 hours and 6 days, and Warner-Bratzler shear force. LWG was strongly affected by production system, being highest for group 1 and lowest for group $4(p<0.001)$. Group 4 had the lowest conformation $(p=0.002)$ and fat scores $(p<0.001)$. Hence, production system affected age at slaughter, live weight gain, weight at slaughter, carcass conformation and fatness scores, but caused no differences in meat quality attributes in intact male lambs.
\end{abstract}

Key words: production system, intact male lamb, live weight gain, $\mathrm{pH}$, colour, Warner-Bratzler shear force

\section{Introduction}

Domestic lamb and sheep meat production was in 20195.090 tonne, which corresponds to 30.7\% of Sweden's total consumption in 2019 (Lannhard Öberg 2020). This suggests that there is potential for expansion of Swedish lamb meat production. Rising demand for high-quality Swedish lamb means that data are needed on the optimal way to rear lamb under Swedish conditions, so as to produce meat with high and consistent eating quality. It is well known that the eating quality and size of valuable cuts of Swedish lamb currently vary more than those of imported lamb and sheep (Carlsson and Arvidsson Segerkvist 2018). Several factors may explain this variation, including some related to primary production such as production system, choice of breed and/or cross, age at slaughter and carcass weight. The Swedish lamb meat production is characterized by few large and many small farms, with a large verity of breeds and production systems (Carlsson and Arvidsson Segerkvist 2018, Lannhard Öberg 2020). The average herd size was 33 ewes and/or rams in 2019 (Jordbruksverket 2019). It has also been shown that feedstuffs and feeding regime can also affect lamb meat quality (Watkins et al. 2013). In particular, pasture and concentrate may have different effects on meat flavour (Fisher et al. 2000, Arsenos et al. 2002, Priolo et al. 2002, Resconi et al. 2009). Feeding strategy can also influence glycogen storage in muscles, which in turn affects post-mortem muscle metabolism and thereby meat quality. Glycogen in muscles is converted into lactic acid under anaerobic conditions after slaughter, which reduces the $\mathrm{pH}$ of the muscle tissue. Since glycogen serves as 'fuel' in this process, it is essential to ensure that glycogen storage in the muscles prior to slaughter is sufficient to enable an adequate decline in $\mathrm{pH}$ (Bendall 1973). The official recommendation in Australia is for crossbred lambs to gain 100-150 g day ${ }^{-1}$ in the last two weeks pre-slaughter, to ensure that the animals are in positive energy balance (growth phase) and have adequate glycogen depots in muscle (MSA 2015a). The effects of different feeding strategies on lamb meat quality can be evaluated by measuring the carcass $\mathrm{pH}$, which is a useful indicator of various meat quality parameters. Specifically, the $\mathrm{pH}$ at 24 hours after slaughter $\left(\mathrm{pH}_{24}\right)$ is commonly used as an indicator of tenderness in meat (Geesink et al. 2000, Thompson et al. 2005, Toohey et al. 2006). Carcass pH (and thus meat quality) is sensitive to many factors pre-slaughter, during slaughter and post-slaughter, and can therefore vary between production systems (Sañudo et al. 1998). It is thus very important to understand how different production systems affect meat quality, in order to help producers deliver the consistent meat quality demanded by consumers.

The aim of this study was to determine how the four most commonly used lamb production systems in Sweden affect live weight gain (LWG), carcass quality and meat quality. The hypotheses tested were that: 1) higher feeding intensity improves growth rate and carcass and meat quality; and 2) concentrate allowance increases LWG, and thus carcass and meat quality. 


\section{AGRICULTURAL AND FOOD SCIENCE}

\section{Material and methods Animals and experimental design}

The experiment was performed between 29 June and 26 October 2016, at SLU Götala Beef and Lamb Research, Swedish University of Agricultural Sciences (SLU), Skara, Sweden $\left(58^{\circ} 42^{\prime} \mathrm{N}, 13^{\circ} 21^{\prime} \mathrm{E}\right)$ and at a private farm outside Skara, Sweden $\left(58^{\circ} 20^{\prime} \mathrm{N}, 13^{\circ} 26^{\prime} \mathrm{E}\right)$. In total, 80 crossbred weaned intact ram lambs (Dorset x Fine Wool) were included in the study, 36 of which were 50:50 crosses and 44 were 75:25 Dorset:Fine Wool crosses. The experiment was approved by the Ethics Committee on Animal Experiments, Gothenburg, Sweden (Registration No. 53-2016). Immediately prior to the study, the lambs were weighed and divided into four groups of 20 individuals each, equally balanced by breed crosses. All lambs were weaned just prior to the study. Average live weight $(26.4 \pm 2.7$, $26.8 \pm 2.8,26.4 \pm 3.1$ and $26.0 \pm 2.7 \mathrm{~kg}$ for group $1,2,3$ and 4 , respectively) and age $(85.25 \pm 6.0,85.2 \pm 5.9,84.45 \pm 5.3$ and $84.4 \pm 6.0$ days for group 1, 2, 3 and 4, respectively) were similar for the four groups at the start of the experiment. Each group was assigned a unique feeding treatment and followed that treatment throughout the experiment, with all groups starting treatment on 29 June. The treatments were: 1 ) indoor rearing; 2 ) cultivated pasture with a concentrate supplement daily; 3 ) only cultivated pasture; and 4) semi-natural pasture (Table 1). Group 4 was reared on the private farm, while the other three groups were reared at SLU Götala Beef and Lamb Research farm.

Table 1. Feeding strategies used for groups 1-4

\begin{tabular}{ll}
\hline Group & Treatment \\
\hline Group 1, indoor & Silage ad libitum + 0.8 kg concentrate per lamb daily \\
Group 2, pasture & Cultivated pasture + $0.3 \mathrm{~kg}$ concentrate per lamb daily* \\
Group 3, pasture & Cultivated pasture with no concentrate \\
Group 4, pasture & Semi-natural pasture with no concentrate \\
\hline *Group 2 received 0.4 kg of concentrate per lamb daily between 28 September and 4 October, \\
due to poor pasture availability.
\end{tabular}

\section{Experimental diets}

Feed values and chemical composition of the experimental feeds are presented in Table 2. Group 1 was fed a diet consisting of silage ad libitum and $0.8 \mathrm{~kg}$ of a standard commercial concentrate (Fårfor Lamm 500, Lantmännen, Västerås, Sweden) per lamb per day to promote rapid growth. The seed mix for the silage consisted of $76 \%$ timothy (Phleum pratense L.), 18\% red clover (Trifolium pratense L.) and 6\% white clover (T. repens L.). The silage was harvested on 27-31 May, and was fertilised in late April with around 30 tonne ha-1 of cattle manure, providing 1.5 $\mathrm{kg} \mathrm{N}$ tonne ${ }^{-1}$. A commercial additive (mixture of formic acid and propionic acid) was added to the herbage before ensiling. The animals in group 1 had free access to water, salt and minerals, and were housed indoors in an enclosed pen made from metal gates and with wheat straw bedding.

Groups 2 and 3 were kept on cultivated pasture in two different enclosures of 1.0 ha, both were divided into three grazing paddocks of 0.3 ha each. Both groups had access to one of the three paddocks at a time and they were moved once a week. Groups 2 and 3 differed in feeding intensity (Table 1), but both groups had daily access to a salt and mineral block and were given free access to water in a tub in each paddock. The seed mix for the cultivated pastures consisted of 50\% timothy, $20 \%$ meadow fescue (Festuca pratensis Huds.), 15\% perennial ryegrass (Lolium perenne L.), 10\% red clover and 5\% white clover. The cultivated pasture for groups 2 and 3 was fertilised on 3 April with $250 \mathrm{~kg}$ of Axan (Yara AB, Malmö, Sweden) (total nitrogen 27.0\%, nitrate nitrogen 13.5\%, magnesium $0.4 \%$, sulphur $3.7 \%$ and calcium $6.0 \%$ ) and then on 5 April with approximately 30 tonne ha-1 of cattle manure $\left(1.5 \mathrm{~kg} \mathrm{~N}\right.$ tonne $\left.^{-1}\right)$. The forage was harvested on 10 June. The regrowth was not fertilised after harvesting.

Group 4 was kept on unimproved semi-natural pasture (Table 2) with daily access to salt and minerals. The seminatural pasture contained trees and shrubs and was on hilly land. This group was moved to new pastures on three occasions (31 August, 8 September, 11 October) due to poor quality and growth of the pasture late in the season. Lambs on semi-natural pasture had free access to water in a pond, stream or tub.

Due to illness, two lambs were removed from the experiment, one from group 1 and one from group 2. Data on these animals were excluded from further analyses, so the results are based on data for 78 lambs in total. 
Table 2. Chemical composition and feeding values of the experimental feeds

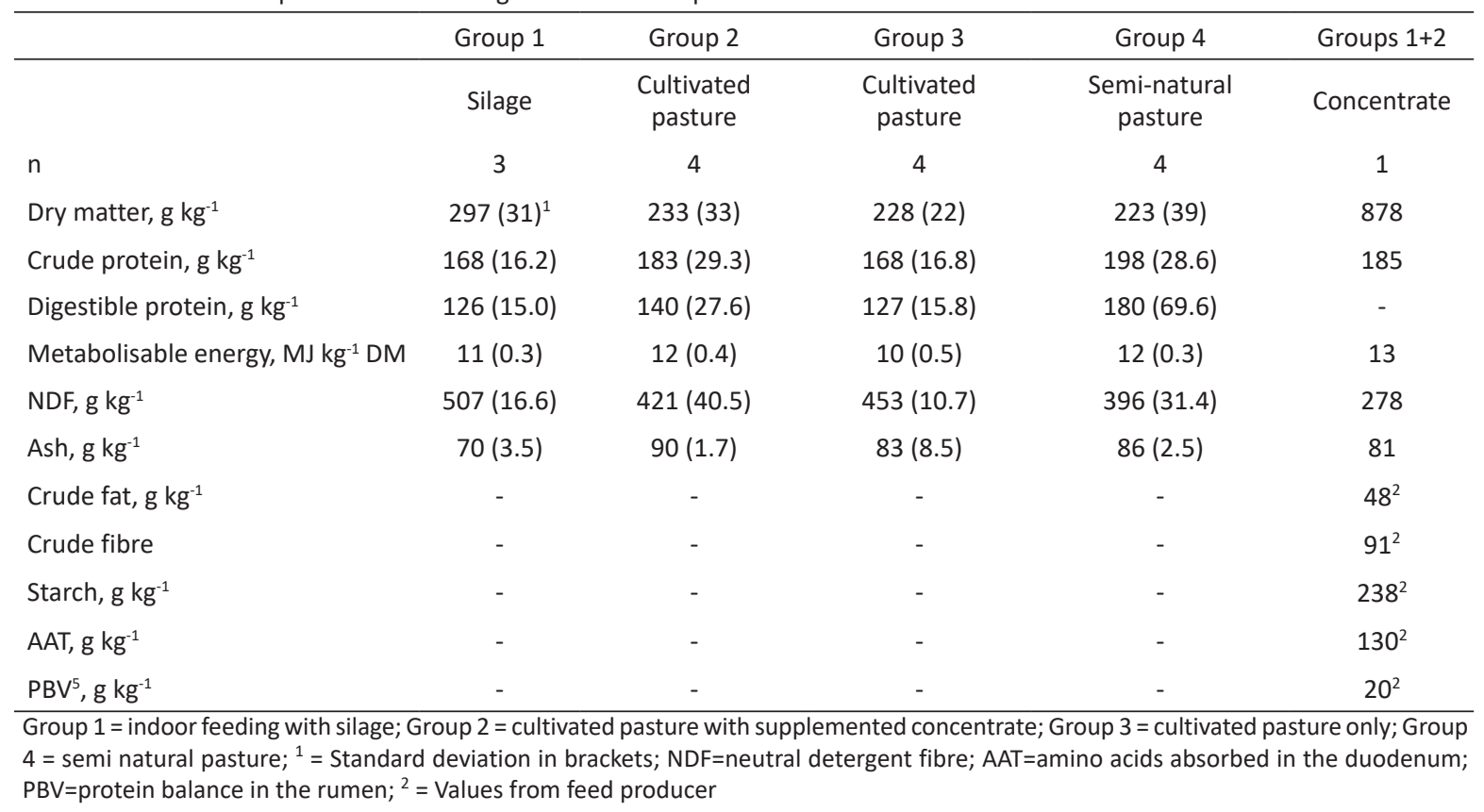

\section{Special treatments during the experiment}

All animals were dewormed (ivermectin, $0.8 \mathrm{mg} \mathrm{ml}^{-1}$ ) at the start of the experiment. All animals other than those in group 1 were dewormed again after four weeks. Animals in group 4 were dewormed a third time, six weeks after the second treatment.

\section{Feed sampling and analyses}

Throughout the experiment, silage samples were collected daily and pasture samples were taken once a week and stored at $-20^{\circ} \mathrm{C}$ until analysis. Pasture samples were cut with a handheld machine, along a W-shaped route in each pasture according to Frame (1993). Before analysis, samples were pooled to obtain representative samples for consecutive 4-week periods. For mineral analysis, samples were pooled to obtain a representative sample for the whole experimental period. The height of the cultivated pastures was measured each week in conjunction with weighing the lambs, immediately before the lambs were released into a new paddock. Sward height was measured according to Frame (1993), following the W-shaped route, with a rising plate meter $(0.3 \times 0.3 \mathrm{~m}$, weight $430 \mathrm{~g}$ ). The same sampling procedure was used for the semi-natural pasture, although the lambs in this group were not moved to a new pasture each week.

Crude protein was analysed according to Dumas (1831) and digestible protein levels were calculated using the digestibility coefficient of Spörndly (2003). Ash content was analysed by combustion at $525^{\circ} \mathrm{C}$. Dry matter (DM) measurement was performed by drying samples at $60^{\circ} \mathrm{C}$ for 16 hours and then at $130^{\circ} \mathrm{C}$ overnight. Neutral detergent fibre (NDF) was analysed as described by Chai and Udén (1998), using $100 \%$ neutral detergent solution, amylase and sulphite. Metabolisable energy (ME) was determined by incubation in rumen fluid and buffer for 96 hours (Lindgren 1979) and then calculating the ME concentration based on in vitro disappearance of rumen organic matter, as described by Lindgren (1983).

\section{Weighing and body condition scoring of the lambs}

All lambs were weighed once a week on a portable scale (Iconix 21, Iconix New Zealand Ltd, New Zealand). Body condition scoring (BCS) was performed according to Swedish standards, using five condition classes ranging from 1 (very lean) to 5 (very fat) (Eggertsen 2007). The target for the lambs for slaughter was BCS 3 and live weight 47$50 \mathrm{~kg}$. The lambs were divided into 10 slaughter groups, with 6-8 animals in each group.

\section{Slaughter}

For practical reasons, all animals were gathered and kept indoors on the farm on the night before slaughter. All had free access to water and silage until transport to a commercial abattoir, located about 10 minutes' drive from 


\section{AGRICULTURAL AND FOOD SCIENCE}

E. Stenberg et al. (2020) 29: 432-441

the farm. All animals were transported in a horse trailer driven by staff from the university (SLU) to the abattoir at approximately 08:00 $\mathrm{h}$. All procedures at the abattoir, such as lairage before slaughter, were varied as little as possible. The lambs were rendered unconscious by captive bolt stunning and then exsanguinated within $6 \pm 2$ seconds. Carcass weight (hot carcass weight $\times 0.98$ ) and carcass grade were recorded. Conformation and carcass fatness were assessed manually by a certified classifier using the EUROP-scale, which has 15 classes ranging from 1 (poor conformation/very low fat) to 15 (very excellent conformation/very high fat). Dressing percentage was calculated as carcass weight/live weight $\times 100$. Muscle $\mathrm{pH}$ was recorded, in the $M$. longissimus muscle, 24 hours after slaughter of each animal (Seven2Go pro, Metler Toledo, Schwerzenbach, Switzerland). Between test occasions, the $\mathrm{pH}$ probe was cleaned with pepsin solution to remove residual protein and with ethanol to remove residual fat, in accordance with the manufacturer's instructions. The probe was then re-calibrated with $\mathrm{pH} 4.0$ and 7.0 buffer solutions.

\section{Meat quality analyses}

All carcasses were hung by the Achilles tendon for six days at $4{ }^{\circ} \mathrm{C}$ and then the right longissimus muscle was collected from the first eight slaughtered animals in each group (in total 32 lambs). Immediately after sampling, these meat samples were vacuum-packed and kept frozen at $-20^{\circ} \mathrm{C}$ until analysis.

For each meat sample, the colour of the thawed meat, weight loss after thawing, weight loss after cooking and Warner-Bratzler shear force (WBSF) of the cooked meat were determined. The preparations required to measure all these physical variables meant that it was only possible to process four samples per day. Therefore, we chose to analyse one sample from each sample group on each day of analysis. An additional seven analysis sessions were performed for the remaining samples. All analyses were completed within two weeks. Before each analysis session, four meat samples (one each from groups 1-4) were removed from the freezer, unpacked, weighed (start weight), repacked in a new vacuum bag and thawed for 15 hours at $4{ }^{\circ} \mathrm{C}$. The samples were then tempered in a $20^{\circ} \mathrm{C}$ water bath for one hour, unpacked and reweighed to get the weight loss after thawing. After removal of the fat cover, colour measurements were performed on the surface of the longissimus muscle, at eight locations, using DigiEye (VeriVide, Enderby, UK) and mean of the eight measurements was calculated. For WBSF measurements, repacked samples were placed in a water bath pre-heated to $75^{\circ} \mathrm{C}$ for one hour or until the core temperature reached $70^{\circ} \mathrm{C}$. The samples were then allowed to cool in ice water for one hour, after which the meat was unpacked, weighed to get cooking loss and then placed in bags to reach room temperature. Cylindrical samples with diameter $15 \mathrm{~mm}$ (7-10 replicates/meat sample) were punched out in the longitudinal direction of the fibres for measurement of WBSF using an Instron 5542 instrument (Instron Ltd., High Wycombe, UK). A total of 7-10 measurements were performed and the mean value was calculated. Each sample was placed in a wedge-shaped recess under the cutting blade. The blade was $1 \mathrm{~mm}$ thick and moved downwards through a rectangular hole at a speed of $50 \mathrm{~mm} \mathrm{~min}^{-1}$. The maximum force measured was used as a measure of the cutting resistance of the sample.

\section{Statistical analysis}

Statistical analyses were performed using the Mixed procedure in SAS (SAS 9.4, SAS Inst. Inc., Cary, NC, USA). Two statistical models of the following forms were created, with production system (with four sub-classes) included as a fixed effect.

Live weight gain, age at slaughter and carcass characteristics were analysed using the model:

$$
Y_{i j}=\mu+P_{i}+e_{i j}
$$

Thawing and cooking loss, colour and WBSF were analysed using a model which included day of analysis as a random effect:

$$
Y_{i j}=\mu+P_{i}+d_{i j}+e_{i j k}
$$

where $Y_{i j}$ is the dependent variable, $\mu$ is the grand mean, $P_{i}$ is the fixed effect of the production system, $d_{i j}$ is the random effect day of analysis, and $\mathrm{e}_{\mathrm{ij}}$ and $\mathrm{e}_{\mathrm{ijk}}$ are the residual error $\left(\sim \mathrm{N}\left(0, \sigma^{2}\right)\right)$. A general Satterthwaite approximation for the denominator degrees of freedom was performed, using the SATTERTH option in SAS.

Differences were considered significant at $p<0.05$ and indicative of tendencies at $0.05 \leq p<0.10$. 


\section{AGRICULTURAL AND FOOD SCIENCE}

\section{Results \\ Feeding intensity and live weight gain}

The amount of pasture available to group $4(5.6 \mathrm{~cm}$ on average over the experimental period) was less than that for the other pasture groups $(9.5 \mathrm{~cm}$ for group $2,9.2 \mathrm{~cm}$ for group 3). Production system had an effect $(p<0.001)$ on LWG, which followed the intensity of the feeding treatments, i.e. group 1 lambs had the highest LWG, followed by group 2, group 3 and group 4, respectively (Table 3). As expected, LWG affected the age at slaughter, which differed between all four groups $(p<0.001)$. Group 4 lambs had the highest age at slaughter. Live weight at slaughter also differed between the groups $(p=0.011)$. Group 1 had the highest live weight at slaughter, while group 2 had higher live weight at slaughter than group 3 (Table 3). There were between-group differences in LWG during the last 14 days pre-slaughter. In group 4, growth rate per day in the last 14 days prior to slaughter exceeded the overall growth rate during the experiment.

\begin{tabular}{|c|c|c|c|c|c|c|}
\hline Parameters & Group 1 & Group 2 & Group 3 & Group 4 & SEM & Significance \\
\hline$n$ & 19 & 19 & 20 & 20 & & \\
\hline LW at start, kg & 26.4 & 26.8 & 26.4 & 26.0 & 0.65 & NS \\
\hline LW at slaughter, kg & $50.6^{\mathrm{a}}$ & $50.3^{\mathrm{ab}}$ & $48.3^{c}$ & $48.9^{\mathrm{bc}}$ & 0.54 & 0.011 \\
\hline Days in experiment & $65^{d}$ & $82^{c}$ & $91^{\mathrm{b}}$ & $109^{a}$ & 2.7 & $<0.001$ \\
\hline Age at slaughter & $149^{a}$ & $167^{b}$ & $177^{c}$ & $194^{d}$ & 2.9 & $<0.001$ \\
\hline LWG, g day ${ }^{-1}$ & $377^{\mathrm{a}}$ & $287^{b}$ & $244^{c}$ & $211^{d}$ & 7.9 & $<0.001$ \\
\hline LWG $14 d^{1}$, g day $^{-1}$ & $322^{\mathrm{a}}$ & $287^{\mathrm{ab}}$ & $244^{b}$ & $319^{a}$ & 0.0 & 0.043 \\
\hline
\end{tabular}

Group 1 is reared by indoor feeding with silage and concentrate; group 2 on cultivated pasture with 0.3 kg concentrate per lamb daily; group 3 on cultivated pasture and group 4 on semi-natural pasture. SEM = standard error of the mean; NS = non-significant $(p>0.05) ;{ }^{a-d}=$ Mean values within rows with different superscripts differ significantly $(p<0.05) ;{ }^{1}=$ Average LWG during the last 14 days pre-slaughter.

\section{Carcass quality}

Production system had a significant effect on carcass weight $(p<0.001)$, with group 4 having lower carcass weight than the other three groups. Group 4 had lower conformation $(p=0.011)$, fat score $(p=0.039)$ and dressing percentage $(p<0.001)$ than all other groups (Table 4$)$.

Table 4. Carcass quality and meat quality of lambs reared using four different production systems

\begin{tabular}{|c|c|c|c|c|c|c|}
\hline Parameter & Group 1 & Group 2 & Group 3 & Group 4 & SEM & Significance \\
\hline \multicolumn{7}{|l|}{ Carcass quality } \\
\hline$n$ & 19 & 19 & 20 & 20 & & \\
\hline Carcass weight & $21.6^{\mathrm{a}}$ & $21.3^{\mathrm{a}}$ & $20.9^{\mathrm{a}}$ & $18.8^{\mathrm{b}}$ & 0.47 & 0.003 \\
\hline Conformation $^{1}$ & $9.2^{\mathrm{a}}$ & $8.7^{\mathrm{a}}$ & $8.7^{\mathrm{a}}$ & $7.9^{b}$ & 0.24 & 0.002 \\
\hline Fatness $^{2}$ & $7.4^{\mathrm{a}}$ & $7.7^{\mathrm{a}}$ & $7.4^{\mathrm{a}}$ & $6.5^{b}$ & 0.17 & $<0.001$ \\
\hline Dressing, \% & $42^{a}$ & $42^{a}$ & $41^{\mathrm{a}}$ & $37^{b}$ & 0.4 & $<0.001$ \\
\hline $\mathrm{pH}_{24}$ & 5.83 & 5.66 & 5.77 & 5.59 & 0.098 & NS \\
\hline \multicolumn{7}{|l|}{ Meat quality } \\
\hline $\mathrm{n}$ & 8 & 8 & 8 & 8 & & \\
\hline Age at slaughter, d & $146^{\mathrm{a}}$ & $163^{b}$ & $172^{c}$ & $193^{d}$ & 3.5 & $<0.001$ \\
\hline $\mathrm{pH}_{6 \mathrm{~d}}$ & 5.45 & 5.40 & 5.45 & 5.41 & 0.032 & NS \\
\hline Thawing loss, \% & 4.3 & 4.8 & 4.1 & 5.0 & 0.40 & NS \\
\hline Cooking loss, $\%$ & 24.3 & 24.1 & 22.8 & 24.2 & 0.87 & NS \\
\hline Colour L* & 37.1 & 37.2 & 36.5 & 35.7 & 0.69 & NS \\
\hline Colour a* & 16.9 & 16.5 & 16.6 & 16.4 & 0.28 & NS \\
\hline Colour b* & 7.5 & 7.0 & 6.8 & 7.1 & 0.31 & NS \\
\hline WBSF, $N\left(\mathrm{~cm}^{2}\right)^{-1}$ & 33.8 & 45.9 & 31.9 & 34.9 & 4.88 & NS \\
\hline
\end{tabular}

Group 1 is reared by indoor feeding with silage and concentrate; group 2 on cultivated pasture with 0.3 kg concentrate per lamb daily; group 3 on cultivated pasture and group 4 on semi-natural pasture. SEM = standard error of the mean; ${ }^{a-b}=M e a n$ values within rows with different superscripts differ significantly $(p<0.05){ }^{2}=$ According the EUROP system, where $1=P-, 2=P, 3=P+, 4=0-, 5=0,6=0+; 7=R-$, $8=\mathrm{R}, 9=\mathrm{R}+, 10=\mathrm{U}-, 11=\mathrm{U}, 12=\mathrm{U}+, 13=\mathrm{E}-, 14=\mathrm{E}$ and $15=\mathrm{E}+{ }^{3}{ }^{3}=$ According the EUROP system, where $1=1-, 2=1,3=1+, 4=2-, 5=2,6=2+$; $7=3-, 8=3,9=3+, 10=4-, 11=4,12=4+, 13=5-, 14=5$ and $15=5+; N S=$ non-significant $(p>0.05)$; WBSF = Warner-Bratzler shear force 


\section{AGRICULTURAL AND FOOD SCIENCE}

E. Stenberg et al. (2020) 29: 432-441

\section{Meat quality indicators and technological meat quality attributes}

There were no differences between groups with respect to the technological meat quality attributes, i.e. $\mathrm{pH}$ after 24 hours, $\mathrm{pH}_{6 \mathrm{~d}}$ (six days after slaughter), thawing loss, cooking loss, colour ( $\mathrm{L}^{*}, \mathrm{a}^{*}$ and $\mathrm{b}^{*}$ ) and WBSF (Table 4).

\section{Discussion}

In this study, higher feeding intensity resulted in higher LWG, with group 1 lambs having the highest LWG, but there was no effect on meat quality attributes. Live weight gain and/or live weight at slaughter differed from those in comparable studies (e.g. Young et al. 1994, Pethick et al. 2005, Campbell et al. 2012).

The LWG values were mostly higher than in previous studies, where some of the treatments described even gave negative LWG (Young et al. 1994, Pethick et al. 2005, Campbell et al. 2012). However, the nutrient content of the feeds used in those studies is only briefly described, so it is difficult to compare the results with those in the present study. The energy content of the cultivated pasture for group 3 was lower than that for group 2, even though both groups grazed the same field (albeit different parts). This difference in energy content was most likely due to differences in the establishment and relative abundance of various plant species, i.e. the sward composition in the pasture, influencing the nutritional content in different areas of the pasture. Although the nutrient content in the semi-natural pasture was good (Table 2), it should be noted that the amount of pasture available for group 4, based on sward height, was less than that for the other pasture groups (groups 2 and 3). This observation is important for understanding the comparatively low growth rate of group 4, which was most likely adversely affected by pasture availability, as the nutritional content of the pasture was high and should have resulted in higher growth. However, the LWG in group 4 lambs $\left(211 \mathrm{~g} \mathrm{day}^{-1}\right)$ was similar to that in a study by Lind et al. (2009), who observed LWG of $230 \mathrm{~g} \mathrm{day}^{-1}$ on semi-natural pastureland in northern Norway. Thus, it can be concluded that rearing lambs on semi-natural pasture in the temperate climate zone is feasible. The LWG $_{14 d}$ for group 4 was higher than the average LWG for the whole rearing period. The reason for this remains unclear. To increase the weight at slaughter for animals reared on semi-natural pastures (group 4), the lambs could: i) be given supplementary feed or ii) lambing time could be brought forward in the spring, in order to enable earlier release to pasture and ensure that the lambs have time to grow and reach slaughter maturity before the nutritional quality and availability of semi-natural pastures decreases in the autumn.

As expected, the high-intensity feeding systems (groups 1 and 2) and the intermediate production system (group 3) all yielded carcasses with higher conformation and fatness scores than the extensive feeding system (group 4). However, although group 4 lambs had the lowest scores for both conformation and fatness, the carcasses would still qualify for the highest payment per kg carcass weight according to the current price list at two Swedish abattoirs (HKScan 2020, KLS 2020). The dressing percentage was lower for group 4 (37\%) compared with the other groups (41-42\%). This could be explained by the higher age at slaughter for group 4 lambs, which is associated with greater loss of weight in terms of head, bones and intestines (Muir et al. 2008). This loss of weight probably did not derive from greater rumen fill at slaughter, since the amount of pasture available to lambs reared under semi-natural conditions was limited. As expected, feeding intensity affected both growth per day and number of days to slaughter. Although group 3 lambs were reared at a lower intensity than those in groups 1 and 2, they were ready for slaughter at around the same time as group 1 and 2 lambs, despite being raised solely on cultivated pasture. Overall, there were no appreciable differences between groups 1, 2 and 3 with respect to carcass conformation and fatness scores.

In meat from groups 1 and 3, the $\mathrm{pH}_{24}$ value exceeded 5.7 which is considered as the upper limit for a good eating quality (MSA 2015b). This outcome was unexpected, since high growth rates are associated with high glycogen storage in muscles, which normally causes the expected post-slaughter $\mathrm{pH}$ decline. However, our results are consistent with those of Pethick et al. (2005), who found that meat from animals fed a high-energy diet had higher $\mathrm{pH}_{24}$ than meat from animals fed low-energy diets. That study also found that the high-energy group unexpectedly lost a greater proportion of glycogen between farm and slaughter than lambs raised on pasture. Pethick et al. (2005) suggested that these animals may have been more predisposed to lose glycogen in response to stress, a trait which could be of metabolic or behavioural origin. In the present study, even though groups 1 and 3 meat had high $\mathrm{pH}_{24}$ values, there was no expected effect of high $\mathrm{pH}$ on the tenderness of the meat (WBSF values). Other studies have found that lower $\mathrm{pH}_{24}$ values are associated with more tender meat, e.g. Devine et al. (1993) found that meat is most tender when its final $\mathrm{pH}$ is 5.5-5.7. Moreover, two of the $\mathrm{pH}_{24}$ values observed in the present study were above the upper limit of 5.7 recommended by Meat Standards Australia (MSA 2015b). Based on this standard, 


\section{AGRICULTURAL AND FOOD SCIENCE}

E. Stenberg et al. (2020) 29: 432-441

there was a risk of meat from groups 1 and 3 having lower eating quality than that from the other groups. Commercial research in New Zealand has established that the desirable $\mathrm{pH}_{24}$ range for lamb is 5.4-5.8, with values of 5.8-6.0 being associated with intermediate quality (Alliance Group Ltd 2010). Based on these criteria, groups 2, 3 and 4 had more numerically preferable $\mathrm{pH}_{24}$ values than group 1.

In the literature, the pH at 24 hours post mortem is often defined as "final" pH (e.g. Koohmaraie et al. 1991, Koohmaraie et al. 1995, Watanabe et al. 1996, McGeehin et al. 2001, Díaz et al. 2002, Priolo et al. 2002, Sañudo et al. 2003, Velasco et al. 2004, Pethick et al. 2005, Teixeira et al. 2005, Majdoub-Mathlouthi et al. 2013, Majdoub-Mathlouthi et al. 2015). However, in the present study a continuous decline in $\mathrm{pH}$ was seen between $\mathrm{pH}_{24}$ and $\mathrm{pH}_{6 \mathrm{~d}}$ (Table 4). In contrast, Koohmaraie et al. (1995) found that the $\mathrm{pH}$ of lamb carcasses 24 hours post mortem $\left(\mathrm{pH}_{24}=5.6\right)$ was identical to that six days later, and that carcass $\mathrm{pH}$ values then rose slightly (to 5.7) between seven and 21 days post mortem. It is thus not clear whether $\mathrm{pH}$ generally drops significantly after 24 hours or not. However, the results presented both in this study and in Koohmaraie et al. (1995), suggest that describing the pH at 24 hours post mortem as "final" or "ultimate" may be inaccurate.

Technological meat quality parameters determined in this study can only be compared with those in previous work to a limited extent. Comparisons between studies are hampered by differences in e.g. feeding intensity, LWG, breed, sex, intact or castrated ram lambs, carcass weight and slaughter method, or the fact that some of these factors are barely described. These differences derive from the many different production systems used for lamb, which have different prerequisites such as climate and tradition. Thus, previous studies have found no differences in WBSF (Berge et al. 2003, Rodrígues et al. 2008, Karaca et al. 2016), significant differences in WBSF (Sañudo et al. 2003), no differences in meat colour (Díaz et al. 2002, Pethick et al. 2005), significant differences in meat colour (Priolo et al. 2002) and no differences in water loss (Díaz et al. 2002, Rodrígues et al. 2008, Karaca et al. 2016) when comparing different lamb types and production systems.

Berge et al. (2003) did not find any differences in WBSF (2.17-3.69 kg, equal to 21.3-36.2 N) between indoor-reared entire male lambs fed concentrate compared with entire male lambs reared on different types of pasture, with or without concentrate. The results in Berge et al. (2003) are not fully comparable with ours, due to differences in animal age at slaughter (3.5-7 months), carcass weight (10.4-19.7 kg) and feeding systems, but were similar to those in our study. Karaca et al. (2016) studied the effect of two feeding systems where lambs were fed a finishing diet of either alfalfa hay $\left(1750 \mathrm{~g} \mathrm{day}^{-1}\right)$ or alfalfa hay $\left(1250 \mathrm{~g} \mathrm{day}^{-1}\right)+500 \mathrm{~g}$ of barley per lamb and day, with both diets balanced to give equal energy intake in the two groups. Live weight gain for both groups (90 and $32 \mathrm{~g}$ day $^{-1}$ ) was low compared with that in the present study, but these values were significantly different. The WBSF values did not differ between groups in that study (45.7 and $43.9 \mathrm{~N})$, as also found in the present study. However, carcass weights reported by Karaca et al. (2016) (17.5 and $15.7 \mathrm{~kg}$ ) were lower than those in the present study. Significant differences in average daily gain between groups were observed in both that and the present study, indicating that differences in growth rate do not automatically result in differences in WBSF. Further, Karaca et al. (2016) found no differences in either meat colour ( $L^{*}, a^{*}$ or $\left.b^{*}\right)$ or cooking loss, corresponding to the results of the present study. A study by Rodrígues et al. (2008) found differences in LWG when comparing different feeding intensities (straw + pelleted commercial concentrate compared with whole barley grain + protein supplement), with a LWG per day of $272 \mathrm{~g}$ for the straw group and $371 \mathrm{~g}$ for the barley group. On the other hand, Rodrígues et al. (2008) did not find any differences in meat colour, WBSF or water-holding capacity. However, carcass weight was lower (by $12 \mathrm{~kg}$ ) than in the present study, hampering direct comparison of the results.

Sañudo et al. (2003) compared different production systems from six European countries, based on either grass or concentrate or a combination of both. The WBSF results in that study revealed significant differences between systems related to different feeding strategies, age at slaughter, carcass weight and breeds. However, the results are not unequivocal, indicating a combined effect of the factors mentioned above on WBSF. Nevertheless, the results indicate that WBSF values are affected by age at slaughter when comparing entire male lambs with similar carcass weights. The youngest animals had the lowest WBSF values in the study by Sañudo et al. (2003), but no such effect was seen in the present study. The lack of differences in technological meat quality attributes in the present study is a positive finding, since it indicates that all four production systems compared can be used in practice without altering the technological properties of the lamb meat. Pethick et al. (2005) found significant differences in LWG when comparing different feeding intensities (pasture, moderate-energy pellet, high-energy pellet, straw). They found no differences in $\mathrm{L}^{*}$ and $\mathrm{b}^{*}$, as in the present study, but observed differences in $a^{*}$, with meat from lambs in the pasture and moderate-energy treatment having a darker red colour than the high-energy pellet group, in contrast to the present study. Pethick et al. (2005) attributed the differences in a* to elevated ultimate $\mathrm{pH}$ levels in the high-energy pellet $(\mathrm{pH}$ 5.66) and straw $(\mathrm{pH}$ 5.67) feeding treatments compared with pasture 
( $\mathrm{pH}$ 5.57) and moderate-energy pellet ( $\mathrm{pH}$ 5.59). This could also explain the lack of differences in colour in the present study, since $\mathrm{pH}_{24}$ did not differ significantly between groups and may therefore not have influenced any of the colours ( $L^{*}, a^{*}$ or $\left.b^{24}\right)$. As in the present study, Díaz et al. (2002) did not observe any differences in colour ( $L^{*}$, $a^{*}$ or $b^{*}$ ) or water-holding capacity when comparing concentrate and pasture for fattening lambs. However, Priolo et al. (2002) recorded differences in $\mathrm{L}^{*}$, with a grass-fed group producing darker meat than the stall-fed group, and saw a tendency for differences in $b^{*}$, with the grass-fed group having a lower yellowness index than a stallfed group. Priolo et al. (2002) attributed the difference in $\mathrm{L}^{*}$ to numerically higher ultimate $\mathrm{pH}$ for the grass-fed group ( $\mathrm{pH}$ 5.62) compared with the stall-fed group ( $\mathrm{pH}$ 5.57). However, this difference was non-significant, and it is thus questionable whether it can explain the difference in $L^{*}$ between grass-fed and stall-fed lambs.

\section{Conclusions}

There were differences in LWG between the four production systems studied here, but the results indicate that intact ram lambs can be reared under intensive or extensive conditions without any differences in meat quality attributes. Parameters affected by the production system included age at slaughter, live weight gain, carcass weight, carcass conformation and fatness scores. Lambs reared on cultivated pasture had better carcass classification (conformation and fatness), as well as carcass weights than those reared on semi-natural pasture. Further studies are needed to evaluate the existing recommendations of $\mathrm{pH}_{24}$ to be 5.7 for meat to identify if this recommendation applies for animal material and production systems used in this study. Studies are also needed on whether $\mathrm{pH}$ at 24 hours post mortem should be described as "final" or "ultimate" $\mathrm{pH}$, since further pH decline in muscle beyond 24 hours has been observed. If $\mathrm{pH}$ measurements are to be carried out later than 24 hours after slaughter, possible correlations between $\mathrm{pH}$ and meat quality attributes, such as tenderness, should be examined.

\section{Acknowledgement}

We thank Jonas Dahl, David Johansson, Karin Wallin and Frida Dahlström for valuable technical support, the staff at Skara lammslakteri for help during slaughter, and Mr Lennart Pettersson, farmer, for good cooperation. We are also grateful to the funding bodies Stiftelsen Svensk Fårforskning, Interreg ÖKS [grant no. 20200994], Västra Götalandsregionen [grant no. RUN-610-0789-13], Agroväst and the Swedish University of Agricultural Sciences for base support.

\section{References}

Alliance Group Ltd 2020. Alliance Group Ltd July 2010. Research into Lamb Meat Quality.

Arsenos, G., Banos, G., Fortomaris, P., Katsaounis, N., Stamataris, C., Tsaras, L. \& Zygoyiannis, D. 2002. Eating quality of lamb meat: effects of breed, sex, degree of maturity and nutritional management. Meat Science 60: 379-387. https://doi.org/10.1016/S0309-1740(01)00147-4

Bendall, J.R. 1973. Postmortem changes in muscle. In: Bourne, G.H. (ed.). Structure and Function of Muscle, New York, USA: Academic Press. p. 243-309. https://doi.org/10.1016/B978-0-12-119102-3.50012-4

Berge, P., Sañudo, C., Sanchez, A., Alfonso, M., Stamataris, C., Thorkelsson, G., Piasentier, E. \& Fisher, A.V. 2003. Comparison of muscle composition and meat quality traits in diverse commercial lamb types. Journal of Muclse Foods 14: 281-300. https://doi.org/10.1111/j.1745-4573.2003.tb00707.x

Campbell, A.W., Maclennan, G., Lindsay, S., Behrent, M.R., Cheong, I. \& Kerslake, J.I. 2012. Brief communication: Exploring the effects of growth rate and meat yield on lamb meat quality. Proceedings of the New Zealand Society of Animal Production 72: $150-151$.

Carlsson, A. \& Arvidsson Segerkvist, K. 2018. Lammlyftet: Identifikation av faktorer som är viktiga för lammkötts kvalitetsegenskaper. Skara: Sveriges Lantbruksuniversitet Instutitionen för husdjurens miljö och hälsa Avdelningen för produktionssystem. Report 47. (in Swedish).

Chai, W. \& Udén, P. 1998. An alternative oven method combined with different tetergent strenghts in the analysis of neutral detergent fiber. Animal Feed Science and Technology 74: 281-288. https://doi.org/10.1016/S0377-8401(98)00187-4

Devine, C.E., Graafhuis, A.E., Muir, P.D. \& Chrystall, B.B. 1993. The effect of growth rate and ultimate pH on meat quality of lambs. Meat Science 35: 63-77. https://doi.org/10.1016/0309-1740(93)90070-X

Díaz, M.T., Velasco, S., Cañeque, V., Lauzurica, S., Ruiz de Huidobro, F., Pérez, C., González, J. \& Manzanares, C. 2002. Use of concentrate or pasture for fattening lambs and its effect on carcass and meat quality. Small Ruminant Research 43: 257-268. https://doi.org/10.1016/S0921-4488(02)00016-0

Dumas, J.B.A. 1831. Procedes de l’Analyse Organique. Annals of Chemistry and of Physics 247: 198-213.

Eggertsen, J. 2007. Utfodring under ett fårår. In: Sjödin, E., Eggertsen, J., Hammarberg, K.-E., Danell, Ö., Näsholm, A., Barck, S., Green, D., Waller, A., Hansson, I., Persson S. \& Kumm, K.-I. (eds.). Får. Stockholm, Sweden: Natur och Kultur. p. 84. (in Swedish). 
Fisher, A.V., Enser, M., Richardson, R.I., Wood, J.D., Nute, G.R., Kurt, E., Sinclair, L.A. \& Wilkinson, R.G. 2000. Fatty acid composition and eating quality of lamb types derived from four diverse breed x production systems. Meat Science 55: $141-147$. https://doi.org/10.1016/S0309-1740(99)00136-9

Frame, J. 1993. Herbage mass. Sward Measurement Handbook. In: Davis, A., Baker, R.D., Grant, S.A. \& Laidlaw, A.S. (eds.). Reading UK: British Grassland Society. p. 39-67.

Geesink, G.H., Bekhit, A.D. \& Bickerstaffe, R. 2000. Rigor temperature and meat quality characteristics of lamb longissimus muscle. Journal of Animal Science 78: 2842-2848. https://doi.org/10.2527/2000.78112842x

HKSCAN 2020. HKScan Agrinotering Nöt, Får \& Lamm. (in Swedish). http://www.hkscanagri.se/notering/. Accessed 19 August 2020

Jordbruksverket 2019. Lantbrukets djur i juni 2019. Farm animals in June 2019. Statistiska meddelanden JO 20 Sm 1901 . (in Swedish). https://www.scb.se/contentassets/5a0620e7b6f3409eaa4e9805f1b721b0/jo0103_2019m06_sm_jo20sm1901.pdf. Accessed 20 November 2020

Karaca, S., Yilmaz, A. \& Kor, A. 2016. The effect of feeding system on slaughter-carcass characteristics, meat quality, and fatty acid composition of lamb. Archives Animal Breeding 59: 121-129. https://doi.org/10.5194/aab-59-121-2016

KLS 2020. Notering år 2020. Notering för KLS Ugglarps. (in Swedish). https://www.klsugglarps.se/information-foer-lantbrukare/ notering-foer-kls-ugglarps/. Accessed 19 August 2020.

Koohmaraie, M., Shackelford, S.D., Wheeler, T.L., Lonergan, S.M. \& Doumit, M.E. 1995. A muscle hypertrophy condition in lamb (Callipyge): Characterization of effects on muscle growth and meat quality traits. Journal of Animal Science 74: $3596-3607$. https://doi.org/10.2527/1995.73123596x

Koohmaraie, M., Whipple, G., Kretchmar, D.H., Crouse, J.D. \& Mersmann, H.J. 1991. Postmortem proteolysis in longissimus muscle from beef, lamb and pork carcasses. Journal of Animal Science 69: 617-624. https://doi.org/10.2527/1991.692617x

Lannhard Öberg, A. 2020. Marknadsrapport FÅR \& LAMM, -utvecklingen till och med 2019. Jordbruksverket. (in Swedish). https:// djur.jordbruksverket.se/download/18.1f4f1aff172b08ab5fb86407/1592231956763/Marknadsrapport\%20lammk\%C3\%B6tt\%20 2020.pdf

Lind, V., Berg, J., Eik, L.O., Eilertsen, S.M., Molmann, J., Hersleth, M., Afseth, N.K \& Haugland, E. 2009. Effects of concentrate or ryegrass- based diets (Lolium multiflorum) on the meat quality of lambs grazing on semi-natural pastures. Acta Agriculturae Scandinavica, Section A-Animal Science 59: 230-238. https://doi.org/10.1080/09064700903493699

Lindgren, E. 1979. Vallfodrets näringsvärde bestämt in vivo med olika laboratoriemetoder. The Department of Animal Nutrition and Management, The Swedish University of Agricultural Sciences, Uppsala, Sweden. Report 45. (in Swedish).

Lindgren, E. 1983. Nykalibrering av VOS-metoden för bestämning av energivärde hos vallfoder. The Department of Animal Nutrition and Management, The Swedish University of Agricultural Sciences, Uppsala, Sweden. (in Swedish).

Majdoub-Mathlouthi, L., Saïd, B., Say, A. \& Kraiem, K. 2013. Effect of concentrate level and slaughter body weight on growth performances, carcass traits and meat quality of barbarine lambs fed oat hay based diet. Meat Science 93: $557-563$. https://doi.org/10.1016/j.meatsci.2012.10.012

Majdoub-Mathlouthi, L., Saïd, B. \& Kraiem, K. 2015. Carcass traits and meat fatty acid composition of Barbarine lambs reared on rangelands or indoors on hay and concentrate. Animal 9: 2065-2071. https://doi.org/10.1017/S1751731115001731

McGeehin, B., Sheridan, J.J. \& Butler, F. 2001. Factors affecting the pH decline in lab after slaughter. Meat Science 58: 79-84. https://doi.org/10.1016/S0309-1740(00)00134-0

MSA 2015a. Tips \& Tools Meat Standrad Australia. The effect of nutrition and growth on sheepmeat eating quality.

MSA 2015b. Tips \& Tools Meat Standrad Australia. The effect of pH on sheepmeat eating quality.

Muir, P.D., Thomson, B.C. \& Askin, D.C. 2008. A review of dressing out percentage in New Zealand livestock. New Zealand: Ministry of Agriculture and Forestry. $88 \mathrm{p}$.

Pethick, D.W., Davidson, R., Hopkins, D.L., Jacob, R.H., D’Souza, D.N., Thompson, J.M. \& Walker, P.J. 2005. The effect of dietary treatment on meat quality and on consumer perception of sheep meat eating quality. Australian Journal of Experimental Agriculture 45: 517-524. https://doi.org/10.1071/EA03255

Priolo, A., Micolo, D., Agabriel, J., Prache, S. \& Dransfield, E. 2002. Effect of grass or concentrate feeding system on lamb carcass and meat quality. Meat Science 62: 179-185. https://doi.org/10.1016/S0309-1740(01)00244-3

Resconi, V.C., Campo, M.M., Font i Furnols, M., Montossi, F. \& Sañudo, C. 2009. Sensory evaluation of castrated lambs finished on different proportions of pasture and concentrate feeding systems. Meat Science 83: 31-37. https://doi.org/10.1016/j.meatsci.2009.03.004

Rodrígues, A.B., Bodas, R., Prieto, N., Landa, R., Mantecón, A.R. \& Giráldez, F.J. 2008. Effect of sex and feeding system on feed intake, growth, and meat and carcass characteristics of fattening Assaf lambs. Livestock Science 116: 118-125. https://doi.org/10.1016/j.livsci.2007.09.016

Sañudo, C., Alfonso, M., Sanchez, A., Berge, P., Dransfield, E., Zygoyiannis, D., Stamataris, C., Thorkelsson, G., Valdimarsdottir, T., Piasentier, E., Mills, C., Nute, G.R. \& Fisher, A.V. 2003. Meat texture of lambs from different European production systems. Australian Journal of Agricultural Research 54: 551-560. https://doi.org/10.1071/AR02092

Sañudo, C., Sanchez, A. \& Alfonso, M. 1998. Small ruminant production systems and factors affecting lamb meat quality. Meat Science 49: 29-64. https://doi.org/10.1016/S0309-1740(98)90037-7

Spörndly, R. 2003. Fodertabeller för idisslare. Sveriges lantbruksuniversitet, Uppsala: Institutionen för husdjurens utfodring och vård. Report 257. (in Swedish).

Teixeira, A., Batista, S., Delfa, R. \& Cadavez, V. 2005. Lamb meat quality of two breeds with protected origin designation. Influence of breed, sex and live weight. Meat Science 71: 530-536. https://doi.org/10.1016/j.meatsci.2005.04.036 
Thompson, J.M., Hopkins, D.L., Souza, D.N.D., Walker, P.J., Baud, S.R. \& Pethick, D.W. 2005. The impact of processing on sensory and objective measurements of sheep meat eating quality. Australian Journal of Experimental Agriculture 45: 561-573. https://doi.org/10.1071/EA03195

Toohey, E.S., Hopkins, D.L., McLeod, B.M. \& Nielsen, S.G. 2006. Quantifying the rate of pH and temperature decline in lamb carcasses at three abattoirs in New South Wales. Australian Journal of Experimental Agriculture 46: 875-878. https://doi.org/10.1071/EA05324

Velasco, S., Cañeque, V., Lauzurica, S., Pérez, C. \& Huidobro, F. 2004. Effect of different feeds on meat quality and fatty acid composition of lambs fattened at pasture. Meat Science 66: 457-465. https://doi.org/10.1016/S0309-1740(03)00134-7

Watanabe, A., Daly, C.C. \& Devine, C.E. 1996. The effects of the ultimate pH of meat on tenderness changes during ageing. Meat Science 42: 67-78. https://doi.org/10.1016/0309-1740(95)00012-7

Watkins, P.J., Frank, D., Singh, T.K., Young, O.A. \& Warner, R.D. 2013. Sheepmeat flavour and the effect of different feeding systems: A review. Journal of Agricultural and Food Chemistry 61: 3561-3579. https://doi.org/10.1021/jf303768e

Young, O.A., Cruickshank, G.J., MacLean, K.S. \& Muir, P.D. 1994. Quality of meat from lambs grazed on seven pasture species in Hawkes Bay. New Zealand Journal of Agricultural Research 37: 177-186. https://doi.org/10.1080/00288233.1994.9513055 